Proc. Estonian Acad. Sci. Geol., 1997, 46, 3, 107-118

\title{
MINERALOGY AND MICROPALAEONTOLOGY OF THE KINNEKULLE ALTERED VOLCANIC ASH BED (ORDOVICIAN) AT PÄÄSKÜLA, NORTH ESTONIA
}

\author{
Olle HINTS, Toivo KALLASTE, and Tarmo KIIPLI
}

Institute of Geology, Estonia Blvd 7, EE-0001 Tallinn, Estonia

Received 14 February 1997, accepted 9 June 1997

Abstract. Investigation of subsurface tunnels in Pääsküla Hillock revealed outcrops of the 27-cmthick Kinnekulle altered volcanic ash bed. Preliminary X-ray diffractometric study showed that the dominating minerals are potassium feldspar and illite-smectite. Palaeontological investigations revealed abundant scolecodonts in the bed, suggesting the infaunal mode of life for some Ordovician polychaete worms. In the studied area, the limestone block above the Kinnekulle bed could have been shifted along the bed due to the pressure of advancing continental ice sheet in the Quaternary.

Key words: Middle Ordovician, North Estonia, Kinnekulle K-bentonite, altered volcanic ash, metabentonite, X-ray diffractometry, potassium feldspar, microfossils, scolecodonts.

\section{INTRODUCTION}

In Estonia the thickest altered volcanic ash bed was first discovered by V. Jaanusson and R. Männil at the end of the 1930s (Jaanusson, pers. comm., 1996). They noted the occurrence of a massive clay bed in the Middle Ordovician limestones in Pääsküla Hillock. Subsequently, volcanic origin of a similar bed was recognized in Sweden by Thorslund (1945) and a wide distribution of the same bed was documented in Baltoscandia (Männil, 1966; Vingisaar, 1972). During the long research history different names have been used to mark the bed: bed XXII (Hageman \& Spjeldnaes, 1955), thick bed (Byström, 1956), bed d (Jürgenson, 1958, 1962), main metabentonite (Männil, 1966; Vingisaar, 1972), bed B (Brusewitz, 1986), and Kinnekulle K-bentonite 
(Bergström et al., 1995). In addition to the above-listed papers, the lithology, mineralogy, and geochemistry of this bed have been-studied by Utsal \& Jürgenson (1971), Vingisaar \& Murnikova (1973), Kepezinskas et al. (1994), Velde \& Brusewitz (1982), Brusewitz (1988). The bed has an important stratigraphical role as its base marks the boundary between the Haljala and Keila stages (Jaanusson \& Martna, 1948; Jaanusson, 1995).

Formerly only two outcrops of the bed had been reported by Rõõmusoks (1970) in the eastern part of its distribution area, in Estonia. One of these is located in Pääsküla Hillock (Fig. 1), where the Kinnekulle bed was exposed on three sites in the 1940s (Jaanusson, pers. comm., 1996); two of the sites are described by Rõõmusoks. Unfortunately, none of these outcrops has preserved. A recently discovered extensive outcrop offers a possibility to trace small-scale lateral changes of the bed and to apply methods which require larger samples than attainable from drill cores.

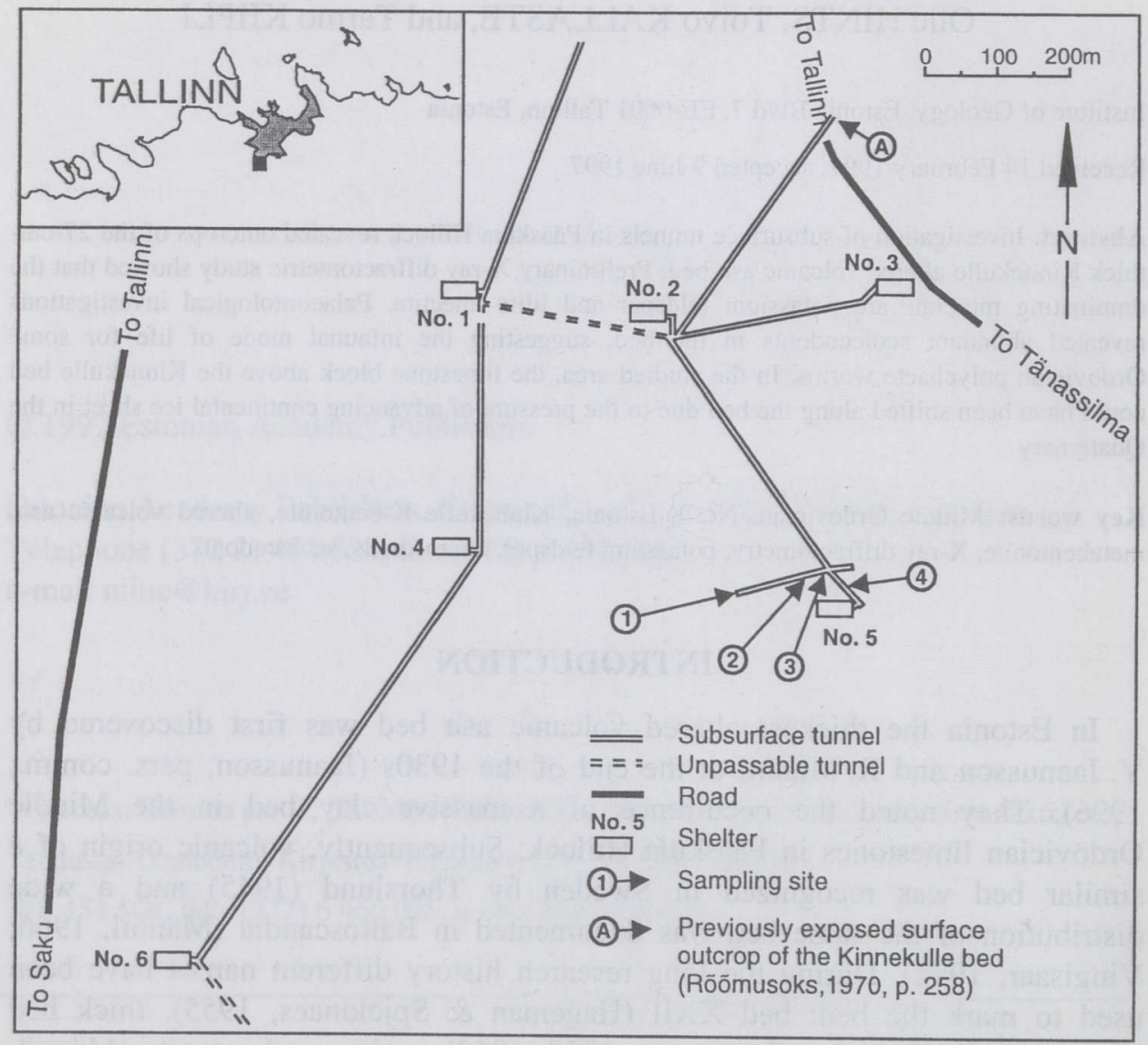

Fig. 1. Sketch map of the study area. 
The present paper describes this new locality and provides some preliminary data on mineralogy and lithology (T. Kallaste, T. Kiipli), and micropalaeontology (O. Hints) of the Kinnekulle bed in Pääsküla Hillock.

In the East Baltic, beds of altered volcanic material are traditionally called metabentonites. In recent years the term $\mathrm{K}$-bentonite has become widely used. As in the studied locality the bed contains often less than $50 \%$ of clay minerals, we prefer the term altered volcanic ash (AVA).

\section{LOCALITY}
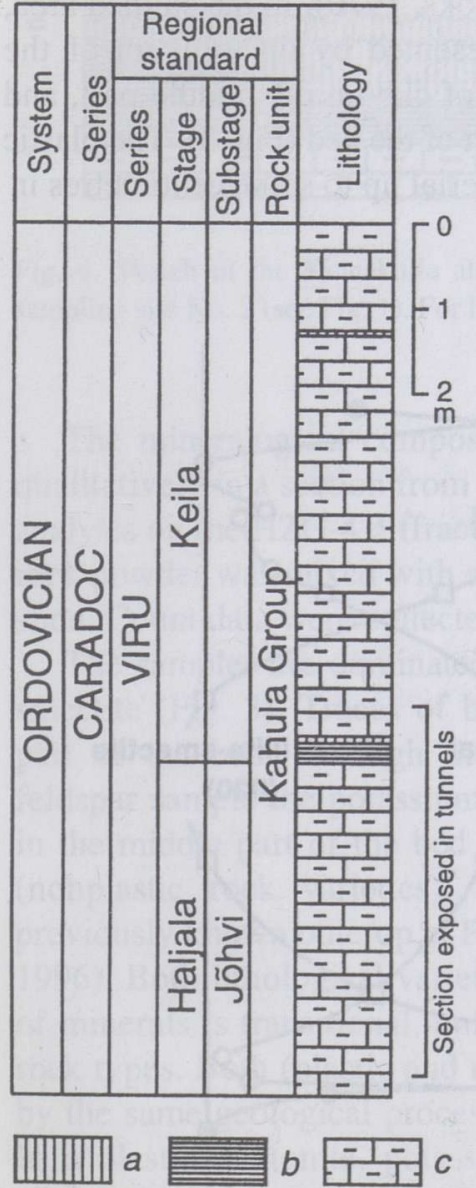

a
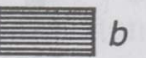

$-1-i d c$

Fig. 2. Stratigraphy and lithology of the Jõhvi Substage and the Keila Stage exposed in Pääsküla Hillock. $a$, nonplastic variety of the altered volcanic ash bed; $b$, plastic variety of the altered volcanic ash bed; $c$, argillaceous limestone.
Pääsküla Hillock is situated at the southern boundary of Tallinn, close to Tallinn-Pärnu highway. A 3-km-long, 2.4-km-wide, and 18-mhigh bedrock elevation in the discussed area (Tavast \& Raukas, 1982) in most part represents the outcrop area of the Keila Stage. The Quaternary cover is seldom thicker than $0.3 \mathrm{~m}$ on the hillock.

Most of the bedrock exposures found in Pääsküla Hillock were made artificially during the construction of the defences by the Russian army in 1913-18. Argillaceous limestones of the Jõhvi Substage and the Keila Stage, embodying two altered ash beds, are exposed in a thickness of over $10 \mathrm{~m}$ (Fig. 2) in various trenches, shelters, and subsurface tunnels. The Kinnekulle AVA is exposed only in 2-4-m-high tunnels dug into bedrock to connect the shelters. The total length of these tunnels exceeds $6 \mathrm{~km}$, but due to the high groundwater level and several falls only $2 \mathrm{~km}$ of it is accessible. Entrances into the tunnels are located in shelters No. 1, 3, 4, and 5 (see Fig. 1) which, except for No. 1, are easily recognizable in landscape.

The extent of the bed exposed in the tunnels is about $900 \mathrm{~m}$ in the east-west and about $1100 \mathrm{~m}$ in the north-south direction. The bed crops out mostly in the walls of the tunnels just below the roof. Less frequently the overlying limestones are exposed above the altered ash bed. 


\section{LITHOLOGY AND MINERALOGY}

The thickness of the Kinnekulle AVA in Pääsküla Hillock is about $27 \mathrm{~cm}$, which is in accordance with Rõommusoks (1970). The lower boundary of the bed is sharp. Underlying limestones are often impregnated with pyrite in a thickness of $2-3 \mathrm{~mm}$. The contact with overlying limestones is, on the contrary, more or less transitional.

The bed contains two visually distinguishable rock varieties with different lithologies - plastic light yellowish-grey clay and hard nonplastic yellow or grey rock. These two varieties have been described in a number of drill cores and they are characteristic of the beds of volcanic origin at different stratigraphical levels in Estonia (Jürgenson, 1958, 1962, 1964; Rõõmusoks, 1970). In the studied area, the vertical section of the AVA is usually represented by up to $1 \mathrm{~cm}$ of the nonplastic variety in the lower part, $15-18 \mathrm{~cm}$ of clay in the middle part, and $8-11 \mathrm{~cm}$ of hard rock with burrows in the upper part of the bed (Fig. 3). The plastic part contains often angular clasts of harder material up to some centimetres in

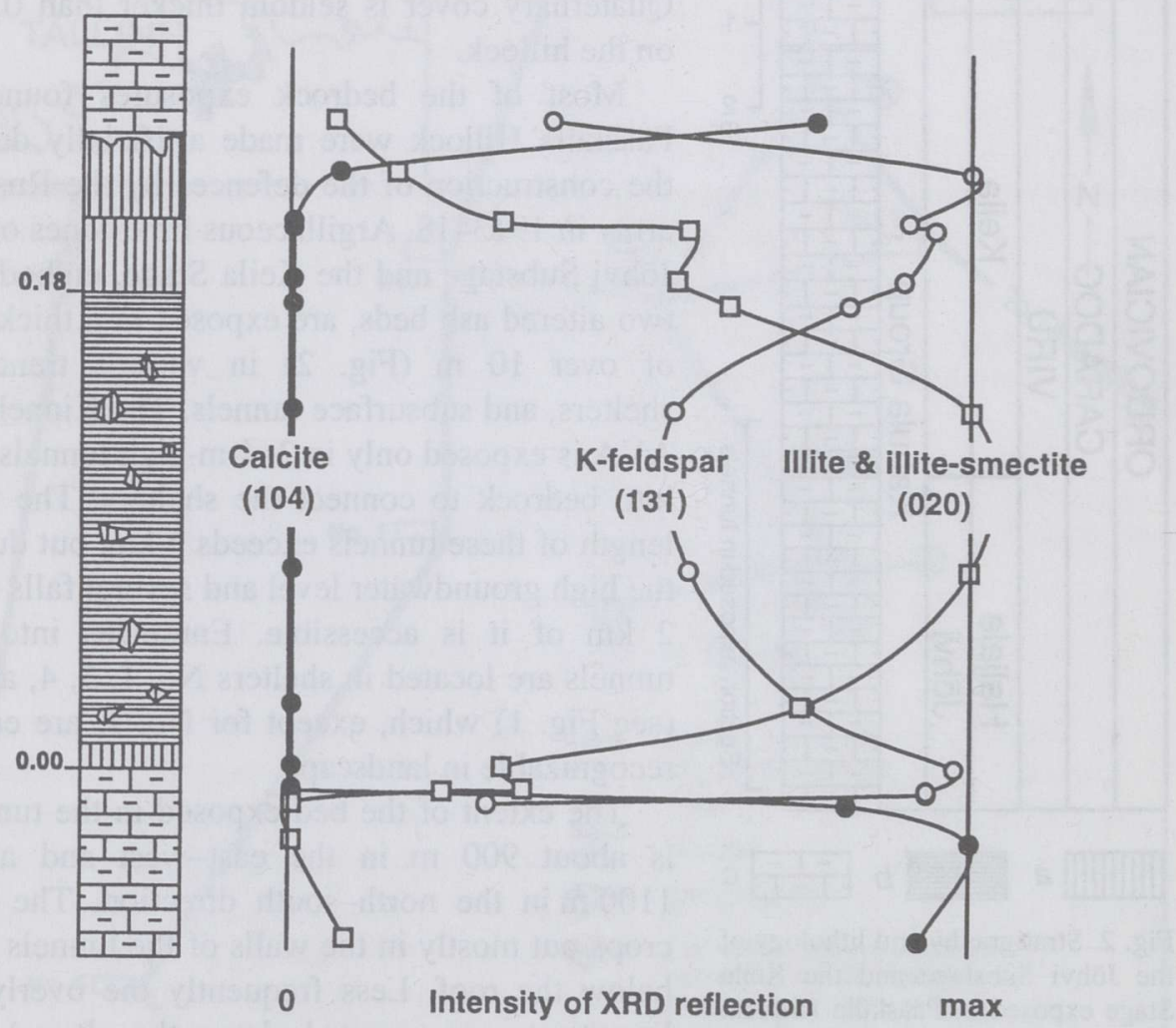

Fig. 3. Lithology and mineralogy of the Kinnekulle altered volcanic ash bed at sampling site No. 3 (see Fig. 1). For lithology refer to Fig. 2. 
size. In some places, the upper hard part is thicker, forming nearly the whole bed. These anomalies, one of which is shown in Fig. 4, are horizontally lens-like, reaching $20 \mathrm{~m}$ in length in the tunnel walls. The total thickness of the bed is stable in these places. The upper surface of the lens-like bodies is easily distinguishable. Thus, the thickness of the "normal" upper part of the bed is also stable. No distinct surrounding rock lithology, faults or fissures were recorded on these sites.

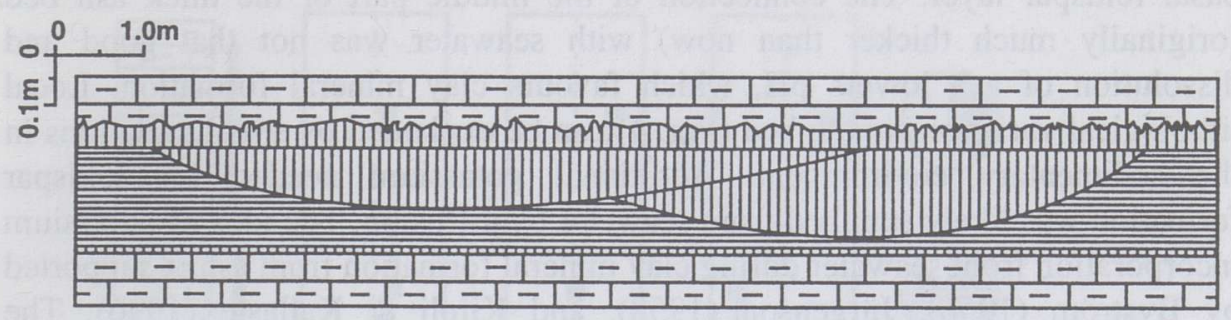

Fig. 4. Sketch of the Kinnekulle altered volcanic ash bed with local nonplastic lenses in it at sampling site No. 2 (see Fig. 1). For lithology refer to Fig. 2.

The mineralogical composition of the samples from the AVA was studied qualitatively in a section from locality No. 3 (Fig. 1) by X-ray powder diffraction analysis on the HZG-4 diffractometer, using Fe-filtered Co radiation. The wholerock powder was mixed with several drops of ethyl alcohol and spread on a glass slide. Count data were collected in the range of 20-44 degrees (two-theta).

The samples are dominated by two minerals - potassium feldspar and illitesmectite (Fig. 3). Traces of biotite and gypsum were recorded from the lower part of the bed. Through the comparison with a pure authigenic potassium feldspar sample the potassium feldspar content was evaluated as being $50-70 \%$ in the middle part of the bed (the plastic rock variety) and $80-90 \%$ at margins (nonplastic rock varieties). The potassium content in a sample from the previously known outcrop at Pääsküla (see Fig. 1) was $13.9 \%$ (Kiipli \& Kallaste, 1996). Both lithological varieties consist of the same two minerals. The content of minerals is transitional, unlike the distinct visual difference between the two rock types. Both (plastic and nonplastic) rock types appear to have been formed by the same geological processes, differing quantitatively, but not qualitatively. In a plastic bentonite, potassium feldspar crystals float in clay. In case of a slightly higher content of feldspar crystals, they form a nonplastic framework.

Usually, the formation of authigenic silicate minerals begins with hydrolysis of vitric ash. Unstable intermediate phases later recrystallize to stable silicates. According to Helgeson \& Mackenzie (1970), the main factors controlling silicate mineral formation in seawater are $\mathrm{pH}$ and silica concentration. Shallow-water limestones, forming the host rock, suggest that high $\mathrm{pH}$ conditions (probably 
around 8.0) could prevail in seawater at the time of volcanic ash deposition. These conditions could be favourable for potassium feldspar formation in the upper part of the ash bed which was in good contact with seawater. A smaller grain size in the upper ash layer could lead to a higher dissolution rate of vitric material, causing a high silica concentration in sediment porewater. The high silica concentration in water promotes feldspar precipitation too. An analogous process, which took place on the contact with carbonate sediment porewater in the lower part of the ash bed, could probably contribute to the formation of a thin basal feldspar layer. The connection of the middle part of the thick ash bed (originally much thicker than now) with seawater was not that good and dissolution of ash lowers $\mathrm{pH}$, which favours clay mineral formation. Local lithological variations in the bed (Fig. 4) can be explained by small variations in the sedimentary environment. Additional potassium needed for feldspar formation was likely supplied from seawater by diffusion. The idea of potassium incorporation from seawater during clay mineral formation from ash is supported by Byström (1956), Jürgenson (1958), and Kiipli \& Kallaste (1996). The formation of K-feldspar and illite-smectite in the conditions of deep burial in North America is described by Hay et al. (1988). This seems improbable at Pääsküla, as it is difficult to find a source (mostly from above) for additional potassium in the surrounding massive limestones. Vertical asymmetric zonation of clay minerals in the thick bentonite bed at Kinnekulle is described by Brusewitz (1986, 1988). She concludes that high temperature driven from diabase dyke alone could not cause variability of clay minerals at Kinnekulle, as changes in their composition do not coincide with the palaeotemperature gradient. Asymmetric zonation of the bed at Pääsküla probably reflects crystallization of authigenic silicate minerals from vitric ash material in the asymmetric environment on the sea bottom or in the conditions of shallow burial.

\section{MICROFOSSILS}

The distribution of organic microfossils was studied in 15 samples (200 g each) from the Kinnekulle AVA and the under- and overlying limestones (Fig. 5). The samples containing soft, clay-rich material were disintegrated in the water; the limestones were processed by means of dilute hydrochloric acid. Residues were washed through a $0.063-\mathrm{mm}$ sieve; microfossils were picked up and stored in glycerine. The main attention was paid to polychaete jaws (scolecodonts) as they were prevailing in all samples of the AVA bed. Polychaete individuals were counted by the number of the most numerous jaw element in the sample, the diversity of the assemblage was estimated by using Simpson's formula (Simpson, 1949)

$$
D=N(N-1) / \sum n(n-1),
$$


where $D$-diversity index, $N$ - number of specimens in a sample, $n$-number of specimens within species. The occurrence of scolecodonts in the volcanoclastic deposits has not been noted previously, but Briggs et al. (1996) discovered fossilized soft parts of several species of polychaete worms from the Wenlockian volcanic deposits in Herefordshire, UK.

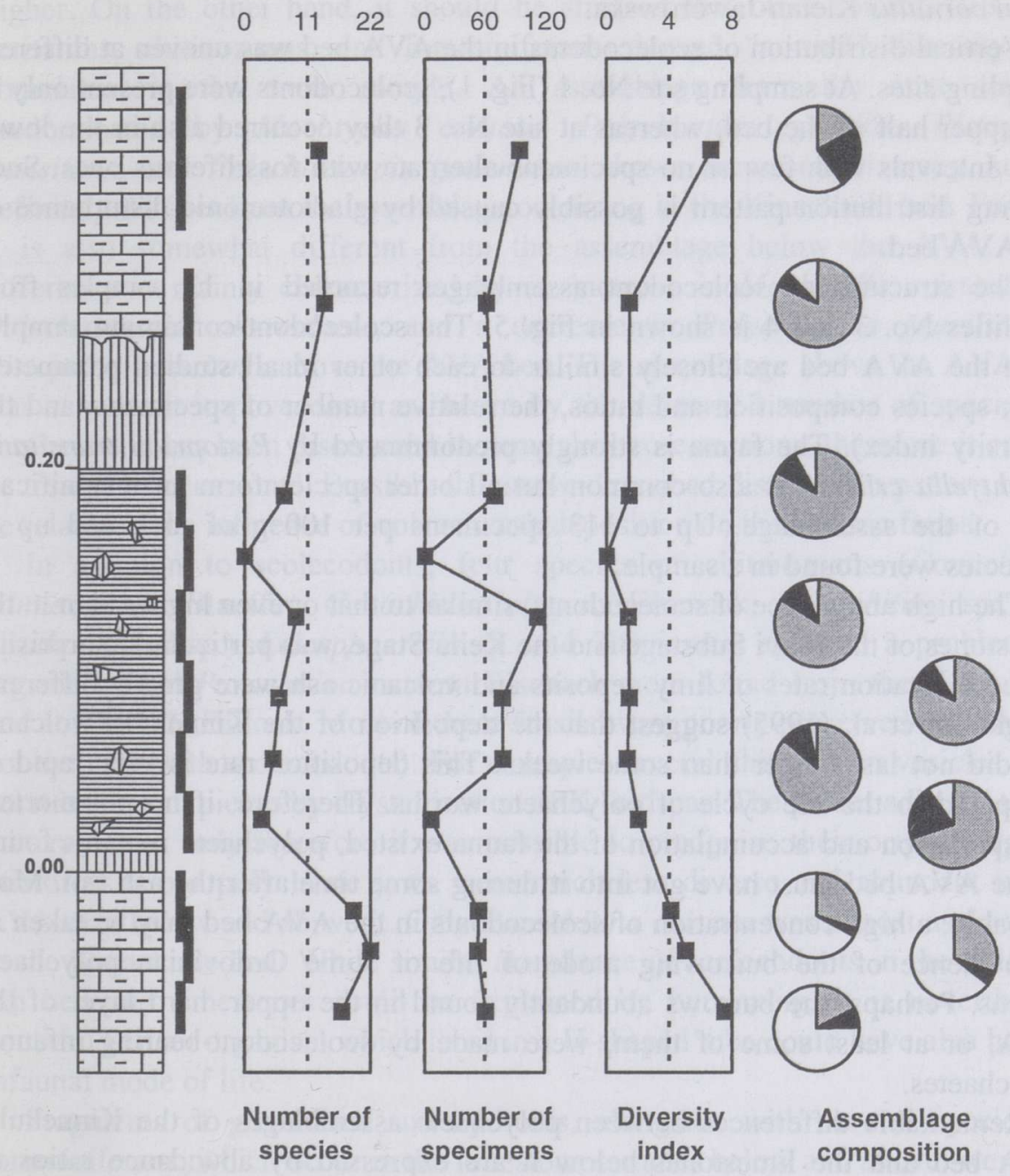

Fig. 5. Composition of scolecodont assemblages in the Kinnekulle altered volcanic ash and in the adjacent limestones based on data from sampling sites No. 3 and 4. In the pie-charts, the shadowed area corresponds to Pistoprion transitans, black area to Mochtyella cristata, and white to all other species. For lithology refer to Fig. 2. 
In the samples studied, altogether 26 species of scolecodonts were found. The AVA bed yielded the following species: Pistoprion transitans KielanJaworowska, Mochtyella cristata Kielan-Jaworowska, "Xanioprion" sp., Tetraprion pozaryskae Kielan-Jaworowska, Polychaetura gracilis Kozlowski, Polychaetura sp. a: Kielan-Jaworowska, Polychaetaspis gadomskae KielanJaworowska, Polychaetaspis tuberculatus Kielan-Jaworowska, "Polychaetaspis" incisus Kielan-Jaworowska, Polychaetaspis sp., Kalloprion sp., and Atraktoprion cornutus Kielan-Jaworowska.

Vertical distribution of scolecodonts in the AVA bed was uneven at different sampling sites. At sampling site No. 1 (Fig. 1), scolecodonts were present only in the upper half of the bed, whereas at site No. 3 they occurred also in the lower part. Intervals with few or no specimens alternate with fossiliferous ones. Such varying distribution pattern is possibly caused by glaciotectonic disturbance of the AVA bed.

The structure of scolecodont assemblages recorded in 11 samples from localities No. 3 and 4 is shown in Fig. 5. The scolecodont-containing samples from the AVA bed are closely similar to each other in all studied parameters (e.g., species composition and ratios, the relative number of specimens, and the diversity index). The fauna is strongly predominated by Pistoprion transitans. Mochtyella cristata is also common but all other species form an insignificant part of the assemblage. Up to 113 specimens per $100 \mathrm{~g}$ of rock and up to 9 species were found in a sample.

The high abundance of scolecodonts, similar to that or even higher than in the limestones of the Jõhvi Substage and the Keila Stage, was particularly surprising as sedimentation rates of limy deposits and volcanic ash were greatly different. Bergström et al. (1995) suggest that the deposition of the Kinnekulle volcanic ash did not last longer than some weeks. This deposition rate is very rapid as compared to the life cycle of polychaete worms. Therefore, if no postmortem transportation and accumulation of the fauna existed, polychaete remains found in the AVA bed must have got into it during some time after the ash fall. Most probably, a high concentration of scolecodonts in the AVA bed may be taken as an evidence of the burrowing mode of life of some Ordovician polychaete worms. Perhaps, the burrows abundantly found in the upper, hard layer of the AVA, or at least some of them, were made by scolecodont-bearing infaunal polychaetes.

Remarkable differences between polychaete assemblages of the Kinnekulle AVA bed and the limestones below it are expressed by abundance ratios of different species and by the diversity index, which is notably higher below the AVA. In the limestone, each of the predominating species (Polychaetura gracilis, Pistoprion transitans, and Polychaetaspis gadomskae) makes up less than $40 \%$, whereas Pistoprion transitans forms on average more than $80 \%$ of all specimens in the Kinnekulle bed. The decreased diversity of the assemblages in the AVA could be explained by different habits of different species. That means, 
Pistoprion transitans could have been a more active burrower than other polychaetes, unless it was just more tolerant to the abnormal conditions in the sediment. The upper boundary of the AVA, in contrast to the lower one, is lithologically not very distinct. Likewise, the changes in the composition of the polychaete assemblage seem to be more or less transitional. The first limestone sample above the AVA contained an assemblage similar to that in the AVA, although the number of species (but not the diversity index) was somewhat higher. On the other hand, it should be stressed that other microfossils, like acritarchs, chitinozoans, and foraminiferans showed "normal" diversity and abundance in the same sample. An assemblage from the next sample, predominated by Mochtyella cristata, Polychaetura gracilis, Pistoprion transitans, and Polychaetaspis gadomskae shows increased diversity and is definitely distinct from the assemblage occurring in the Kinnekulle bed. Further, it is also somewhat different from the assemblage below the AVA. That difference is mainly characterized by an increase in Mochtyella cristata and Polychaetaspis tuberculatus, and a decrease in Polychaetura gracilis and Pistoprion transitans above the AVA bed. The assemblage above the AVA bed was somewhat impoverished as sho, $n$ by the decreased number of species. A similar trend has been discovered in seme crill core sections, therefore it cannot be treated as occasional. Possibly the avove-described distribution pattern might be related to the influence of volcanic ash deposition on the benthic fauna.

In addition to scolecodonts, four species of chitinozoans (Conochitina minnesotensis Stauffer, Conochitina elegans Eisenack, Conochitina sp., and Cyathochitina sp.), Leiosphaeridia sp. and Tasmanites sp., and a problematic organic-walled Parachitina curvata Eisenack were found from the Kinnekulle bed at Pääsküla Hillock. Most of these fossils ivere poorly preserved (which was not the case with scolecodonts). For example several chitinozoan vesicles have burst into small pieces by crystallization of $\mathrm{K}$ - eldspar. The pieces adhered to the mineral mass, only therefore it was possible to recognize their origin. Organic microfossils but polychaete jaws were much less diverse and abundant in the AVA than below and above it. Only Parachitina curvata was almost as frequent in the Kinnekulle bed. While similar abundance of scolecodonts in the volcanic ash bed and limestones could be explained by burrowing, it is nevertheless doubtful that an organism which lived in a U-shaped tube could have also had an infaunal mode of life.

Fragments of graptolites and hydroids, alongside with several species of foraminiferans, which occur in the limestone samples below and above, were not found in the AVA bed.

\section{GLACIAL DEFORMATIONS}

The formation of Pääsküla Hillock has been strongly influenced by glaciers of Quaternary age, due to which the bedrock elevation was formed. Several 
deformations, most probably of glacial origin, can also be observed in the Kinnekulle AVA bed.

The plastic rock variety of the bed contains often unrounded particles of harder material, presumably derived from the lower or the upper part of the bed. Such brecciation was almost indistinguishable in the field, but clearly visible when the AVA was dried or, on the other hand, disintegrated in water. In one place near shelter No. 4, limestones were also brecciated below the AVA bed, which ordinarily had no strict lower boundary. Besides, the distribution pattern of microfauna would be difficult to explain by any other way than by distortion of the bed. The fissures that occur in the rocks with the AVA bed are not continuous. They are "cut" by the AVA bed and their parts above and below this bed are located not directly over one another but have some horizontal distance $(0.7-1.5 \mathrm{~m}$ in the tunnel between shelters No. 4 and 6). All that may suggest that the upper part of the bedrock elevation, composed of limestones of the Keila Stage, has been shifted southwards along the thick altered volcanic ash bed by the pressure of glaciers in the Quaternary as proposed previously by L. Ainsaar (pers. comm., 1996).

\section{CONCLUSIONS}

1. Two visually distinct lithological varieties of the AVA bed have a similar mineralogical composition. The main minerals are: prevailing K-feldspar and illite-smectite, varying in proportions in different samples.

2. Asymmetric vertical compositional zonation of the AVA bed probably reflects an inhomogeneous early diagenetic environment on the ancient seafloor and bottom sediments. Compositional variations in space probably show small variations in facies conditions.

3. Organic microfossils, including scolecodonts, chitinozoans, and acritarchs are present in some parts of the Kinnekulle AVA bed. Their abundance, except that of scolecodonts, and diversity are much lower than in the adjacent limestones. High abundance of scolecodonts could be explained by the infaunal mode of life of some polychaete worms.

4. Differences between the assemblages of scolecodonts below and above the AVA might reflect some influence of volcanic ash fall on the benthic fauna.

5. The upper part of the bedrock elevation in Pääsküla Hillock could have been shifted by Quaternary glaciers along the AVA bed. This has caused some deformations of the bed.

\section{ACKNOWLEDGEMENTS}

We are grateful to V. Jaanusson for consultation and to J. Nõlvak who kindly verified identifications of some microfossils. Our thanks are also due to 
E. Jürgenson, T. Meidla, I. Puura, and K. Kirsimägi for reading the manuscript and making many useful comments, and to L. Ainsaar for discussion on glaciotectonics. This work is a contribution to the research programme supported by the grants No. 1935 and 2651 of the Estonian Science Foundation.

\section{REFERENCES}

Bergström, S. M., Huff, W. D., Kolata, D. R. \& Bauert, H. 1995. Nomenclature, stratigraphy, chemical fingerprinting and areal distribution of some Middle Ordovician K-bentonites in Baltoscandia. $G F F, 117,1-13$.

Briggs, D. E. G., Siveter, David J. \& Siveter, Derek J. 1996. Soft-bodied fossils from a Silurian volcanoclastic deposit. Nature, 382, 248-249.

Brusewitz, A. M. 1986. Chemical and physical properties of Paleozoic potassium bentonites from Kinnekulle, Sweden. Clays and Clay Minerals, 34, 442-454.

Brusewitz, A. M. 1988. Asymmetric zonation of a thick Ordovician K-bentonite bed at Kinnekulle, Sweden. Clays and Clay Minerals, 36, 349-353.

Byström, A. M. 1956. Mineralogy of the Ordovician bentonite beds at Kinnekulle, Sweden. Sver. Geol. Undersökn., Ser. C, No. 540, 1-62.

Hageman, F. \& Spjeldnaes, N. 1955. The Middle Ordovician of the Oslo region, Norway. Norsk Geologisk Tidsskrift, 35, 29-51.

Hay, R. L., Lee, M., Kolata, D. R., Matthews, J. C. \& Morton, J. P. 1988. Episodic potassic diagenesis of Ordovician tuffs in the Mississippi Valley area. Geology, 16, 743-747.

Helgeson, H. C. \& Mackenzie, F. T. 1970. Silicate - sea water equilibria in the ocean system. Deep-sea Research, 17, 877-892.

Jaanusson, V. 1995. Confacies differentiation and upper Middle Ordovician correlation in the Baltoscandian basin. Proc. Estonian Acad. Sci. Geol., 44, 2, 73-86.

Jaanusson, V. \& Martna, J. 1948. A section from the Upper Chasmops Series to the Lower Tretaspis Series at Fjäcka rivulet in the Siljan area, Dalarna. Bull. Geol. Instns Univ. Uppsala, 32, 183-193.

Jürgenson, E. 1958. Metabentonites in Estonian S.S.R. In Geoloogia Instituudi Uurimused, II. Eesti Riiklik Kirjastus, Tallinn, 73-85 (in Russian).

Jürgenson, E. 1962. Vulkaanilise päritoluga setted Eesti aluspõhjas. Eesti Loodus, 4, 229-230.

Jürgenson, E. 1964. Silurian metabentonites of Estonian S.S.R. In Litologiya paleozojskikh otlozhenij Estonii. Institut Geologii, Tallinn, 87-100 (in Russian).

Kepezinskas, K., Laškovas, J. \& Šimkevicius, P. 1994. The Ordovician metabentonites of the Baltic region as a reflection of volcanic activity in the Iapetus palaeoocean and Tornquist Sea. Geologija (Lituaniae Acad. Sci.), 16, 34-42.

Kiipli, E. \& Kallaste, T. 1996. Geochemical characterization of some Estonian metabentonites. Proc. Estonian Acad. Sci. Geol., 45, 2, 68-77.

Männil, R. 1966. Evolution of the Baltic Basin During the Ordovician. Valgus, Tallinn (in Russian).

Rõomusoks, A. 1970. Stratigraphy of the Viruan Series (Middle Ordovician) in Northern Estonia. Valgus, Tallinn, (in Russian).

Simpson, E. H. 1949. Measurements of diversity. Nature, 163, 688.

Tavast, E. \& Raukas, A. 1982. The Bedrock Relief of Estonia. Valgus, Tallinn (in Russian).

Thorslund, P. 1945. Om bentonitlager i Sveriges kambrosilur. GFF, 67, 286-288.

Utsal, K. \& Jürgenson, E. 1971. The mineralogy of Estonian metabentonites. Eesti NSV TA Toim. Keemia, Geol., 20, 4, 336-348 (in Russian). 
Velde, B. \& Brusewitz, A. M. 1982. Metasomatic and non-metasomatic low grade metamorphism of Ordovician metabentonites in Sweden. Geochim. Cosmochim. Acta, 46, 447-452.

Vingisaar, P. 1972. On the distribution of the main metabentonite stratum (d; XXII) in the Middle Ordovician of Baltoscandia. Eesti NSV TA Toim. Keemia, Geol., 21, 1, 62-70 (in Russian).

Vingisaar, P. \& Murnikova, T. 1973. New data on the mineralogy of some Estonian Lower Caradocian metabentonites. Eesti NSV TA Toim. Keemia, Geol., 22, 2, 149-158 (in Russian).

\title{
VULKAANILISE PÄRITOLUGA KINNEKULLE KIHI (ORDOVIITSIUM) MINERALOOGIA JA MIKROPALEONTOLOOGIA PÄÄSKÜLA KÕVIKUL
}

\author{
Olle HINTS, Toivo KALLASTE ja Tarmo KIIPLI
}

Pääsküla kõviku maa-aluste tunnelite uurimisel ilmnesid Kinnekulle muutunud vulkaanilise tuhakihi ulatuslikud paljandid. Kihi paksus on orienteerivalt $27 \mathrm{~cm}$. Röntgendifraktomeetriline analüüs näitas, et kiht koosneb kahest põhimineraalist - kaaliumpäevakivist, mille sisaldus kõigub 50-90\% piires, ning illiit-smektiidist. Kinnekulle muutunud tuhakihi mikropaleontoloogilisel uurimisel avastati ohtralt skolekodonte. Tõenäoliselt viitab see mõnede hulkharjasusside kuulumisele infauna koosseisu. Võimalik, et tuhakihi peal lasuvad lubjakivid on mandrijää survel kõviku vanemate kihtide suhtes nihutatud.

\section{МИНЕРАЛОГИЯ И МИКРОПАЛЕОНТОЛОГИЯ СЛОЯ ИЗМЕНЕННОГО ВУЛКАНИЧЕСКОГО ПЕПЛА КИННЕКУЛЛЕ (ОРДОВИК) В ПЯЭСКЮЛА, СЕВЕРНАЯ ЭСТОНИЯ}

\section{Олле ХИНТС, Тойво КАЛЛАСТЕ и Тармо КИЙПЛИ}

При изучении подземных выработок в районе выступа коренных пород в Пяэскюла были обнаружены среди карадокских известняков обширные обнажения слоя измененного вулканического пепла Киннекулле (мощность около 27 см). Рентгенодифрактометрическое изучение показало преобладание в слое аутигенного калиевого шпата (50-90\%), вторым по содержанию минералом был иллит-смектит. Микропалеонтологическое исследование выявило здесь обилие сколекодонтов - челюстей аннелид, которые, по крайней мере часть из них, являлись представителями инфауны. Известняки выше слоя Киннекулле оказались сдвинутыми, повидимому, под давлением континентального ледника. 